\title{
GRAMATIKALISASI DALAM PETUNJUK PERLATIHAN BUKU TEKS BAHASA INDONESIA SMA KELAS $X$
}

\author{
Hindra Kurniawam \\ Pascasarjana, Universitas Negeri Surabaya \\ Email: hindra.kurniawan@mail.unesa.ac.id
}

\begin{abstract}
Abstrak
Kalimat petunjuk pelatihan buku teks memuat perintah-perintah yang harus dipahami dan dikerjakan siswa sesuai yang diinginkan penulis. Hal tersebut bertujuan untuk siswa berlatih mengevaluasi hasil belajarnya. Bentuk perubahan gramatikal dalam teks bertujuan agar siswa lebih mudah dalam mengkap makna yang terdapat dalam petunjuk pelatihan buku teks. Untuk dapat lebih memahami bentuk perubahan gramatikalisasi, berikut disajikan proses gramatikalisasi dalam buku teks Bahasa Indonsia Dalam proses gramatikalisasi, akan ada perubahan makna akibat perubahan dan susunan gramatikal dalam perubahan bentuk dan struktur kalimat. Makna tersebut dapat berupa makna baru atau masih mempertahankan makna lama yang masih bertahan. Makna baru muncul apabila dalam kalimat tersebut dilesapkan atau ditambah unsur intinya. Akibat dari perubhan unsur kalimat inti maka pola pikir pembaca mengalami perubahan dalam memprediksikan maksud utaman dalam memberi petunjuk perlatihan pada t. Makna yang tidak mengalami perubahan merupakan kalimat yang unsur intinya tetap bertahan meskipun telah mengalami proses gramatikalisasi, sehingga maksud yang disampaikan $n$ kepada t tetap sama dan tidak mengalami perubahan. Pertama ditemukannya proses desemantisasi yang dialami oleh petunjuk perlatihan dikarenakan oleh hilangnya unsur semantik dalam kata sehingga mengalami makna yang semakin sempit dan terfokus pada satu maksud tuturan. Dalam analisi desemantisasi ditemukan perubahan maksud kalimat sebagai hasil analisis sebagian berbeda dan ada yang sebagian mengalami kerancuan. Karena kerancuan tersebut dapat menyebabkan $t$ mengalami disorientasi tentang apa yang harus dilakukan terhadap tugas yang telah diberikan oleh $n$. Perubahan makna dalam desemantisasi yaitu makna afektif menjadi temati, makna tematik menjadikonseptual, makna tematik menjadi kolokatif, dan makna afektif menjadi konotatif. Perubahan makna tersebut tidak lepas dari proses desemantisasi namun makna tersebut memiliki nilai rasa yang berbeda di setiap jenisnya.
\end{abstract}

Kata Kunci: gramatikalisasi, makna, perlatihan 


\begin{abstract}
Sentence textbook training manual contains commands that must be understood and carried out as desired student authors. It aims to train students evaluatetheir learning results. Grammatical form changes in the text aims to enable students more easily to reveal a meaning of an instructions contained in a textbook training. Better to understand a changes in grammatically forms, are presented in a textbook process Indonesiangrammatically. In agrammatically process, there will be changes due to become different in meaning,grammatically composition form and structure of a sentence. A meaning can be a new or meaning still retain an old meaning which still survive.A new meaning appear when experiencing a reduction in a sentence element or elements added point. Changes in a core elements as a result of a sentence to change a reader mindset, in predicting a primary purpose of giving guidance $n$ at $t$ on his practice.Meaning that unchanged is a core element of a sentence that remain despite has develop a grammaticallyprocess, so intent submitted $n$ to $t$ remains a same and unchanged. The first discovery process experienced by a guidance desemanticization of his practice due to the loss of semantic elements within a meaning of a word so that experienced more narrow and focused on one speechpurpose.A first discovery process experienced by a guidance lose specific semantic features of human practicing caused by a loss of semantic elements within the meaning of the word so that experienced more narrow and focused on one purpose speech.In an analysis of a sentence mean desemanticization found changes as a result of an analysis partly different and there are mostly suffered ambiguity. Because of an ambiguity can cause $t$ disoriented about what to do with a task that given by $n$. Desemanticization meaning that changes in affective meaning into thematic, thematic meaning becomes a conceptual, thematic meaning into collocation, and affective be connotative meaning. The meaning of a changes can not be separated from the desemanticization process but that meaning has a value different flavors in each type.
\end{abstract}

Keywords: grammatically process, meaning, practicing

\title{
PENDAHULUAN
}

Manusia memerlukan instrumen dalam kegiatan interaksi dengan sesama. Instrumen tersebut berfungsi untuk mengekspresikan diri dan mengungkapkan maksud dan tujuan interaksi. Intrumen tersebut disebut bahasa. Keraf (1997:1) menyatakan bahasa memunyai dua pengertian, yaitu alat komunikasi antaranggota masyarakat yang berupa simbol bunyi yang dihasilkan alat ucap manusia, dan sistem komunikasi yang menggunakan simbol-simbol vokal yang 
arbitrer. Dengan demikian, dapat disimpulkan bahwa bahasa dimiliki oleh manusia, karena dihasilkan oleh artikulasi manusia. Artikulasi manusia berupa seperangkat alat-alat ucap meliputi bibir, gigi, tekak, lidah, pita suara, dan pangkal tenggorok.

Fungsi bahasa dibedakan menjadi dua jenis, yaitu fungsi transaksional dan fungsi interaksional (Brown dan Yule, 1996:1). Bahasa transaksional digunakan untuk menyampaikan informasi faktual atau proporsional. Bahasa transaksional terdapat dalam berita, buku, perkuliahan, seminar, dan lainnya. Bahasa interaksional digunakan untuk memantapkan dan memelihara hubunganhubungan sosial. Bahasa interaksional terdapat dalam sapaan, basa-basi, dan seterusnya.

Berbeda dengan Brown dan Yule, Halliday (1985: 40-65) mengemukakan fungsi bahasa secara makro sebagai berikut. Pertama, fungsi ideasional yaitu fungsi bahasa sebagai wahana untuk mengekspresikan sesuatu. Fungsi ini juga berkaitan dengan peran bahasa untuk mengungkapkan isi, mengungkapkan pengalaman penutur tentang dunia nyata, termasuk dunia dalam kesadarannya sendiri. Kedua, fungsi interpersonal yakni peran bahasa untuk menyampaikan pesan yang dapat meningkatkan hubungan sosial diantara anggota masyarakat. Fungsi ini berkaitan dengan peran bahasa untuk membangun dan memelihara hubungan sosial. Ketiga, fungsi tekstual yakni fungsi bahasa untuk menyediakan kerangka, mengorganisasikan wacana yang relevan dengan situasi. Fungsi ini menyangkut tugas bahasa untuk membentuk berbagai mata rantai kebahasaan dan mata rantai unsur situasi yang memungkinkan digunakannya bahasa oleh pemakainya.

Berdasarkan dua teori fungsi bahasa yang diungkap oleh Brown dan Yule dan Halliday di atas, dapat dinyatakan bahwa fungsi transaksional meliputi fungsi ideasional dan tekstual. Fungsi interaksional terdapat dalam fungsi interpersonal. Tiap-tiap fungsi saling berhubungan karena dalam interaksi, tuturan dapat mencerminkan beberapa fungsi sekaligus. Misalnya, pada seminar, ditemukan 
tuturan dengan fungsi interpersonal atau interaksional, dan fungsi transaksional atau ideasional.

Fungsi tekstual akan tampak pada teks. Hal ini didasarkan pada keadaan teks yang tidak dapat berubah, sedangkan tuturan secara lisan dipengaruhi oleh keadaan petutur, situasi tutur sehingga pola dalam menyampaikan sesuatu dapat berbeda. Teks disusun, dikonsep dan diedit oleh penulisnya. Dengan rangkaian dalam proses penyusunan teks, maka teks yang sudah ada menjadi data valid dalam analisis fungsi bahasa, khususnya fungsi tekstual.

Para linguis, filsuf bahasa, dan ahli psikolinguistik memberi perhatian khusus pada pengguna bahasa untuk menyampaikan informasi faktual atau proporsional. Pengggunaan bahasa tersebut dalam berupa bahasa lisan dan bahasa tulis. Sosiolog, dan alhi sosiolinguistik memberi perhatian pada penggunaan bahasa sehari-hari untuk membentuk dan memelihara hubungan sosial. Berdasarkan perhatian tersebut, maka teks merupakan kajian linguis, filsuf bahasa dan ahli psikolinguistik untuk menelaah informasi faktual dalam teks.

Saussure menyatakan bahwa waktu mengubah segalanya, begitu juga bahasa juga tidak dapat lepas dari hukum universal ini (Aitchison, 2000: 4). Pernyataan Saussure tersebut menyimpulkan bahwa semua bahasa yang ada di dunia ini pasti mengalami perubahan, baik lisan atau teks. Perubahan tersebut dapat berupa perubahan simbol, gaya, stilistika, dan banyaknya jargon. Perubahan tersebut sangat tampak pada bahasa lisan. Khusus untuk bahasa tulis atau teks, ada kaidah yang mengatur tata cara dan kaidah penulisan. Dengan aturan teks tersebut, teks memiliki kelebihan dibandingkan dengan bahasa lisan.

Perubahan tersebut sudah dipresiksi oleh Trask. la menyatakan setiap bahasa secara konstan pasti mengalami perubahan dalam kosakata, pengucapan dan tata bahasa/gramar (1994: 3). Diantara tiga perubahan tersebut, hal yang paling menarik untuk diteliti adalah tata bahasa. Saussure berfokus pada sintaksis karena sintaksis adalah sistem bahasa yang benar-benar internal 
sehingga sistem bahasa memiliki peran yang sangat penting dalam membentuk keseluruhan sistem linguistik suatu bahasa (Rahardi, 2004; Santoso, 2008).

Perubahan bahasa dapat disebut sebagai usaha pengekonomisan bahasa, seperti dapat dilihat dengan memudarnya penggunaan infleksi. Salah satu perubahan bahasa yang sangat jelas menunjukkan adanya usaha ekonomisasi bahasa adalah gramatikalisasi. Gramatikalisasi (Halliday, 241) adalah perubahan bahasa yang terkait dengan pereduksian aspek semantis (semantic weakening, semantic fading).

Salah satu proses penggramatikalan atau gramatikalisasi adalah melalui hilangnya fitur semantis. Suatu komponen tata bahasa direduksi fitur semantisnya untuk menjadi komponen tata bahasa lain. Hal ini nampak jelas dari perubahan kategori leksikal menjadi kategori fungsi. Kategori leksikal merupakan kategori yang dianggap lebih "kaya" (fitur semantis lebih banyak) sementara kategori fungsi adalah kebalikannya (fitur semantis sedikit). Hal ini sesuai dengan Prinsip Ekonomi Fitur yaitu "meminimalisasi fitur semantis pada derivasi" (Halliday). Kategori yang lebih kaya berubah menjadi kategori yang lebih "miskin".

Berdasarkan uraian tersebut, pereduksian fitur semantis, suatu komponen akan menjadi lebih ekonomis dan memenuhi fungsi tata bahasa yakni menjadikan bahasa seringkas mungkin agar komunikasi dapat terjalin baik. Misalnya semakin sedikit tuturan, tetapi, memiliki daya ilokusi dan perlukusi yang banyak, maka tuturan tersebut adalah tuturan yang baik. Tuturan yang singkat dengan ciri ini terdapat dalam teks, yaitu teks kurikulum 2013, khususnya pada teks petunjuk.

Dari sudut pandang buku teks pelajaran, Bahasa Indonesia merupakan media berinteraksi antara peserta didik dengan materi pelajaran. Bahasa Indonesia digunakan untuk menyampaikan konsep keilmuan dan seperangkat kompetensi yang seharusnya dimiliki dan dikembangkan dalam pembelajaran. Bahasa Indonesia digunakan untuk memahami tahapan yang harus dilakukan peserta didik dalam mengembangkan kompetensinya. Bahasa Indonesia digunakan sebagai wahana berpikir peserta didik dalam memahami konsep dan aplikasinya.

Bahasa Indonesia dalam bahan ajar dituntut dapat menjelaskan konsep sesuai dengan perkembangan intelektual peserta didik. Bahasa Indonesia yang digunakan harus 
Hindra Kurniawam, Gramatikalisasi dalam Petunjuk...(hal. 160 - 188)

sesuai dengan kematangan sosial emosional peserta didik dalam mengusung konsep lokal sampai dengan global. Bahasa Indonesia yang digunakan harus menarik dan jelas agar mendorong peserta didik untuk mempelajari bahan ajar sampai dengan tuntas. Bahasa Indonesia yang digunakan dalam bahan ajar seharusnya menggunakan bentuk kata, istilah, kalimat, dan paragraf yang sesuai dengan kaidah bahasa untuk berkomunikasi tertulis.

Kebijakan buku teks pelajaran sebagaimana tertuang di dalam Peraturan Menteri Pendidikan Nasional Republik Indonesia (Permendiknas ) Nomor 11 Tahun 2005 mengatur tentang fungsi, pemilihan, masa pakai, kepemilikan, pengadaan, dan pengawasan pengunaan buku teks pelajaran. Menurut Peraturan Menteri ini, buku teks pelajaran adalah buku acuan wajib untuk digunakan di sekolah yang memuat materi pembelajaran dalam rangka peningkatan keimanan dan ketakwaan, budi pekerti dan kepribadian, kemampuan penguasaan ilmu pengetahuan dan teknologi, kepekaan dan kemampuan estetis, potensi fisik dan kesehatan yang disusun berdasarkan standar nasional pendidikan. Buku teks pelajaran berfungsi sebagai acuan wajib oleh guru dan pesertadidik dalam proses pembelajaran.

Buku teks pelajaran hendaknya mampu menyajikan bahan ajar dalam bahasa Indonesia yang baik dan benar. Di sini dapat dilihat apakah penggunaan bahasanya wajar, menarik, dan sesuai dengan perkembangan siswa atau tidak. Aspek keterbacaan berkaitan dengan tingkat kemudahan bahasa (kosakata, kalimat, paragraf, dan wacana) bagi siswa sesuai dengan jenjang pendidikannya, yakni hal -hal yang berhubungan dengan kemudahan membaca bentuk tulisan atau topografi, lebar spasi dan aspekaspek grafika lainnya, kemenarikan bahan ajar sesuai dengan minat pembaca, kepadatan gagasan dan informasi yang ada dalam bacaan, dan keindahan gaya tulisan, serta kesesuaian dengan tatabahasa baku.

Penelitian tentang gramatikalisasi jarang dilakukan. Penelitian perubahan gramatikal dalam petunjuk pelatihan buku teks Bahasa Indoensia belum pernah dilakukan. Oleh karena itu, peneliti akan meneliti gramatikalisasi dalam teks petunjuk pelatihan dalam buku teks Bahasa Indonesia. Penelitian ini akan lebih dominan dalam penentuan perubahan gramatikal yang ada dalam petunjuk pelatihan untuk siswa yang ada dalam buku teks. Gramatikalisasi yang dimaksud 
adalah bentuk perubahan bahasa yang digunakan pengarang dalam memberikan instruksi pada siswa tentang tugas atau pelatihan yang diberikan agar lebih mudah dalam memahami maksud yang diharapkan penulis pada siswa.

\section{METODE}

Sesuai dengan fokus dan tujuan penelitian, dalam penelitian ini diggunakan pendekatan kualitatif dengan metode deskriptif. Penelitian kualitatif bersifat uraian yang diarahkan untuk mengungkapkan gejolak-gejolak fakta secara sistematis dan akurat. Penelitian ini dilakukan dengan mendeskripsikan data berupa kata dan kalimat petunjuk pelatihan dalam buku teks kelas $\mathrm{X}$. Penggunaan metode deskriptif didasari pertimbangan bahwa data dalam petunjuk pelatihan buku teks memuat makna yang dinamis. Makna tersebut dapat diungkap dengan memaparkan bentuk-bentuk gramatikalisasi sesuai dengan fokus penelitian. Penguraian melalui deskripsi mendalam dan menyeluruh diharapkan mampu mencapai tujuan penelitian, yaitu mendeskripsikan dan menemukan bentuk-bentuk gramatikalisasi serta makna yang muncul dari proses gramatikalisasi (Muslich, 2010; Moleong, 2002).

Sumber data penelitian ini ialah buku teks pelajaran Bahasa Indonesia Ekspresi dan Akademik kelas X SMA edisi pertama yang diterbitkan Kemdikbud dan telah mengimplementasikan Kurikulum 2013. Buku teks pelajaran wajib kelas $\mathrm{X}$ ini telah disetujui oleh pemerintah dan diedarkan secara gratis melalui Buku Sekolah Elektronik (BSE) yang bisa diunduh melalui internet. Untuk menguji tingkat pemahaman siswa terhadapa kalimat hasil proses gramatikalisasi, maka peneliti menggunakan responden 40orang siswa homogen sebagai sumber data yang akan mengerjakan serangkaian pelatihan dengan kalimat petunjuk yang telah mengalami proses gramatikalisasi

Data penelitian ini adalah kalimat petunjuk dalam pelatihan yang tercantum dalam buku teks siswa kelas $\mathrm{X}$. Kalimat-kalimat dala petunjuk pelatihan tersebut diasumsikan memiliki fenomena perubahan kebahasaan yang 
terbentuk dalam proses gramatikalisasi. Jumlah teks yang dijadikan bahan analisis tidak dibatasi. Pengambilan data akan dihentikan jika sudah mendapatkan gambaran serta penjelassan gramatikalisasi yang terjadi dalam buku teks. Data dalam penelitian ini juga berasal dari hasil respons siswa berupa hasil uji pemahaman terhadap petunjuk pelatihan dengan mengerjakan lembaran tugas yang telah diberi petunjuk di setiap pelatihannya.

Pengumpulan data menggunakan metode dokumentasi. Teknik yang digunakan dalam pengumpulan data dalam penelitian ini adalah teknik catat. Instrument kunci dalam penelitian ini adalah peneliti yang mengumpulan data, menetapkan fokus, menganalisis data kemudian menyimpulkan untuk menjawab fokus penelitian. Sebagai pengumpul data, peneliti terlibat langsung dan tidak dapat digantikan dengan instrumen lain dalam aktivitas pengumpulan data. Selain itu, peneliti juga berperan sebagai penafsir dan pembanding dari data yang telah dikumpulkan. Sebagai penafsir, peneliti berperan untuk menginterpretasi data dari petunjuk pelatihan buku teks Bahasa Indonesia.

Peneliti juga berperan sebagai pembanding dengan cara membandingkan data secara cermat untuk menemukan persamaan antardata yang sesuai dengan fokus penelitian. Data yang memiliki persamaan, kemudian dikelompokkan sesuai klasifikasi data yang ditemukan. Hasil dari pengelompokan ini kemudian dicatat dan disertakan pula kode sumber datanya untuk pengecekan ulang pada sumber data dalam rangka analisis data.

Teknik deskriptif merupakan teknik analisis data yang dilakukan dengan cara mendeskripsikan data sesuai dengan rumusan masalah dan teori yang diambil. Data yang terkumpul selanjutnya akan dianalisis. Analisis data diurutkan sesuai dengan rumusan masalah penelitian. Dalam penelitian ini, proses analisi data menggunakan metode deskripsional.

Setelah tahap penyediaan data dilakukan, data yang sudah terkumpul mulai dianalisis. Tahap analisis data ini merupakan upaya peneliti menangani 
langsung masalah yang terkandung pada data. Analisis itu dilakukan saat penyediaan data tertentu yang relevan selesai dilakukan; dan analisis yang sama diakhiri jika kaidah yang berkenaan dengan objek yang menjadi masalah itu telah ditemukan.

Metode yang digunakan dalam upaya menemukan kaidah dalam tahap analisis ada dua, yaitu metode padan dan metode agih. Dalam metode padan, alat penentunya di luar, terlepas, dan tidak menjadi bagian dari bahasa (langue) yang bersangkutan. Sedangkan metode agih, alat penentunya justru bagian dari bahasa yang bersangkutan itu sendiri. Teknik pada metode padan maupun metode agih dapat dibedakan menjadi dua: teknik dasar dan teknik lanjutan (Sudaryanto, 1993).

Analisis data dalam penelitian ini menggunakan metode agih beserta teknik dasar dan teknik lanjutannya. Metode agih adalah metode analisis data yang alat penentunya justru bagian dari bahasa itu. Alat penentu dalam rangka kerja metode agih itu selalu berupa bagian atau unsur dari bahasa objek sasaran penelitian itu sendiri, seperti kata (kata ingkar, preposisi, adverbia), fungsi sintaksis (subjek, objek, predikat), klausa, silabe kata, titinada, dan yang lain (Sudaryanto, 1993: 15-16).

Teknik pada metode agih dapat dibedakan menjadi dua: teknik dasar dan teknik lanjutan. Teknik dasar metode agih disebut teknik bagi unsur langsung atau teknik BUL.

\section{HASIL DAN PEMBAHASAN}

Berdasarkan rumusan masalah, ada dua hal yang dibahas dalam penelitian ini, yaitu (1) proses gramatikalisasi dalam petunjuk pelatihan dan (2) makna yang muncul akibat proses gramatikalisasi 


\section{Proses Gramatikalisasi dalam Petunjuk Pelatihan}

Kalimat petunjuk pelatihan buku teks memuat perintah-perintah yang harus dipahami dan dikerjakan siswa sesuai yang diinginkan penulis. Hal tersebut bertujuan untuk siswa berlatih mengevaluasi hasil belajarnya. Bentuk perubahan gramatikal dalam teks bertujuan agar siswa lebih mudah dalam mengkap makna yang terdapat dalam petunjuk pelatihan buku teks. Untuk dapat lebih memahami bentuk perubahan gramatikalisasi, berikut disajikan proses gramatikalisasi dalam buku teks Bahasa Indonsia

\section{Proses Desemantisasi}

Salah satu proses penggramatikalan atau gramatikalisasi adalah dengan hilangnya fitur semantis. Suatu komponen tatabahasa direduksi fitur semantisnya untuk menjadi komponen tatabahasa lain. Data dalam buku teks dapat disajikan sebagai berikut

(01) Marilah kita uraikan teks berjudul Makhluk di Bumi Ini.

$$
\text { (Pr.De.1/4) }
$$

Kalimat tersebut merupakan kalimat ajakan yang bertujuan untuk mengajak siswa mengerjakan sebuah pelatihan yang terdapat dalam buku teks. Kata marilah dalam data mengindikasikan $n$ sebagai penulis ingin mengajak $t$ sebagai siswa untuk mengerjakan pelatihan. Penggunaan kata tersebut mengakibatkan bernilai rasa lebih halus dalam pemaknaan karena bukan merupakan kalimat direktif yang secara implisit mengajak $t$. Ditinjau dari prinsip kesopanan, siswa memiliki keleluasaan untuk menjalankan kalimat ajakan tersebut sehingga $t$ tidah secara langsung mendapatkan perintah yang disamarkan menjadi ajakan. Ditinjau dari aspek semantik kalimat tersebut mengajak siswa untuk menguraikan sebuah teks bacaan berjudul Makluk di Bumi Ini sesuai dengan struktur isi teks dan menjabarkannya ke dalam bentuk uraian klasifikasi pernyataan umum dan khusus. untuk mengetahui keintian dari kalimat 
tersebut maka ide tidak muncul jika pola kalimat diubah dengan dengan berbagai alternatif kalimat yang telah mengalami proses pelesapan seperti dalam kalimat berikut ini

(01a) Kita uraikan teks yang berjudul makhluk di bumi ini

Kalimat tersebut mengalami pelesapan dengan menghilangkan kata marilah. Penghilangan tersebut mengakibatkan perubahan makna yang terkandung dalam kalimat perintah. Setelah mengalami pelesapan, kalimat tersebut berubah tidak lagi menjadi kalimat direktif sehingga berubah menjadi kalimat informasi pada t tentang kegiatan yang dapat dilakukan terhadap teks Makhluk di Bumi Ini. Dapat disimpulkan bahwa kata Marilah merupakan unsur inti dalam kalimat tersebut, bila unsur tersebut dihilangkan makna akan mengalami perubahan makna dalam kalimat.

Berbeda dengan pola (01a) pelesapan juga dilakukan pada dua unsur kalimat dengan menhilangkan dua kata dalam kalimat sebagai berikut

(01b) Uraikan teks berjudul Makhluk di Bumi ini.

Dari hasil pelesapan tersebut, kata marilah kita dihilangkan. Namun dari ide yang muncul tidak ada perbedaan dengan kalimat awal. Kalimat tersebut tetap mempertahankan bentuk direktifnya untuk memerintahkan siswa menguraikan teks berjudul Makhluk di Bumi ini. Penghilangan marilah kita tidak mengakibatkan perubahan makna yang signifikan sehingga dua kata tersebut jika dihilangkan secara bersamaan bukanlah unsur inti dalam kalimat.

Berbeda dengan data sebelmnya yang berbentuk persuasif dengan bentuk ajakan pada $\mathrm{t}$ untuk mengerjakan pelatihan, pada data berikut ini $\mathrm{n}$ menggunakan bentuk kalimat imperatif. Kalimat inperatif yang bertujuan untuk memerintahkan siswa untuk membaca bacaan. Berikut adalah data yang dapat dianalisis.

(02)Bacalah teks pendek yang berjudul "Sistem Peredaran Darah Manusia" berikut ini! (Pr.De.1/14) 
Kalimat tersebut di atas merupakan kalimat imperatif. Kata bacalah mengindikasikan $\mathrm{n}$ sebagai penulis memerintahkan $\mathrm{t}$ sebagai siswa untuk membaca teks pendek yang berjudul "Sistem Peredaran Darah Manusia". Penggunaan kata bacalah memiliki nilai rasa tegas sebab $\mathrm{n}$ sebagai penulis memerintahkan secara langsung kepada n sebagai siswa untuk membaca. Untuk mengetahui inti kalimat tersebut, dilakukan pelesapan pada kata bacalah seperti yang tampak pada kalimat berikut.

(02a) Teks pendek yang berjudul "Sistem Peredaran Darah Manusia" berikut ini!

Setelah mengalami pelesapan, kalimat tersebut mengalami perubahan makna. Meskipun di akhir kalimat tetap diigunakan tanda baca seru (!) namun kalimat tersebut tidak dapat dikatakan sebagai kalimat perintah yang baik. Hal tersebut terjadi karena tidak jelasnya perintah apa yang diberikan t sebagai penulis kepada $\mathrm{n}$ sebagai siswa. Dengan mengabaikan tanda seru (!), kalimat tersebut telah berubah fungsi menjadi kalimat deklarasi. Dengan perubahan fungsi tersebut, kalimat tersebut memiliki makna memberikan informasi mengenai adanya teks pendek yang berjudul "Sistem Peredaran Darah Manusia". Dengan berubahnya makna setelah terjadinya pelesapan tersebut, dapat disimpulkan bahwa kata bacalah merupakan unsur inti dalam kalimat tersebut.

Untuk mengetahui inti kalimat, selain digunakan pelesapan satu kata, dilakukan pula pelesapan dua kata.

(02b) Pendek yang berjudul "Sistem Peredaran Darah Manusia" berikut ini!

Pelesapan dua kata seperti yang tampak pada kalimat di atas menjadikan kalimat tersebut tidak lengkap dan tidak bermakna. Pelesapan kata bacalah teks telah menghilangkan makna kalimat tersebut. Berdasarkan hal tersebut, dapat dikatakan bahwa unsur inti dari kalimat tersebut adalah bacalah. 
Berdasarkan data yang telah dianalisis sebelumnya, data beriku ini masih dalam bentuk imperatif. Namun menggunakan kalimat perintah yang berbeda, $n$ tidak memerintahkan $\mathrm{t}$ untuk melakukan sesuatu dan hanya memperhatikan ubahan kata dasar menjadi kata bentukan. Petunjuk tersebut disajikan dengan data sebagai berikut.

(03)Perhatikan beberapa contoh pembentukan kata dari kata dasar menjadi kata-kata bentukan yang lain berikut ini. (Pr.De.1/10)

Sama halnya dengan data (02), data (03) juga merupakan kalimat imperatif. Meskipun tidak memiliki partikel -lah, kata perhatikan dalam data mengindikasikan $t$ sebagai penulis menyuruh $n$ sebagai siswa untuk memerhatikan beberapa contoh pembentukan kata dari kata dasar menjadi kata-kata bentukan yang lain. Penggunaan kata perhatikan menjunjukkan bahwa t sebagai penulis memberikan perintah secara langsung dan tegas pada $\mathrm{n}$ sebagai siswa atau pembaca. Untuk mengetahui inti kalimat dari data (03) dilakukan pelesapan seperti yang tampak pada kalimat berikut.

(03a) Beberapa contoh pembentukan kata dari kata dasar menjadi kata-kata bentukan yang lain berikut ini.

Kalimat di atas mengalami pelesapan pada kata perhatikan. Pelesapan tersebut mengakibatkan perubahan makna yang semula memerintah menjadi memberikan informasi mengenai contoh pembentukan kata. Berdasarkan perubahan tersebut, dapat disimpulkan bahwa inti kalimat pada data (03) adalah kata perhatikan.

Selanjutnya, pelesapan dilakukan dengan menghilangkan dua kata pada kalimat awal. Kata yang dilesapkan adalah perhatikan dan beberapa sehingga tampak kalimat berikut.

(03b) Contoh pembentukan kata dari kata dasar menjadi kata-kata bentukan yang lain berikut ini. 
Pelesapan dua kata pada data (03) telah merubah fungsi kalimat yang semua merupakan kalimat imperatif menjadi kalimat deklaratif. Dengan berubahnya fungsi tersebut, berubah pula makna pada kalimat tersebut. Data (03) memiliki makna memerintah siswa untuk memerhatikan contoh pembentukan kata sedangkan data (03b) hanyalah memberikan informasi mengenai adanya contoh pembentukan kata. Makna yang ada pada kalimat (03b) ini sama halnya dengan makna yang ada pada kalimat (03a). Berdasarkan hal tersebut, dapat disimpulkan bahwa inti kalimat pada kalimat (03) adalah kata perhatikan sebab pelesapan yang dilakukan telah merubah makna kalimat.

Selanjutnya, perhatikan data (04) berikut yang tergolong kalimat inperatif. Kalimat imperatif berfungsi memberi komando untuk melakukan sesuatu seperti yang dituliskan pada data berikut ini.

(04) Sambil kalian membaca teks, amati apakah teks ini tergolong ke dalam laporan yang ideal. (Pr.De.1/13)

Kalimat tersebut di atas merupakan kalimat imperatif yang bertujuan untuk menyuruh siswa mengamati teks laporan. Kata amati dalam data mengindikasikan bahwa $\mathrm{n}$ sebagai penulis menyuruh $\mathrm{n}$ sebagai siswa atau pembaca untuk mengamati teks laporan sehingga dapat mengetahui ideal tidaknya teks laporan yang sedang di bacanya. Ditinjau dari segi semantik, kalimat tersebut mengindikasikan agar siswa mengamati teks laporan dengan memerhatikan aspek struktur dan kebahasan yang menjadi cirri khas dari teks laporan. Dengan memerhatikan kedua aspek tersebut siswa akan dapat memberikan penilaian mengenai baik buruknya teks yang dibacanya. Untuk mengetahui keintian dari kalimat tersebut di atas, dilakukan pelesapan untuk mengetahui terjadi tidaknya perubahan makna pada kalimat tersebut.

(04a) Sambil kalian membaca teks, apakah teks ini tergolong ke dalam laporan yang ideal. 
Kalimat tersebut di atas mengalami pelesapan dengan menghilangkan kata amati. Penghilangan tersebut mengakibatkan perubahan makna dalam kalimat tersebut. Kalimat tersebut tidak lagi menjadi kalimat imperatif melainkan seolaholah telah menjadi kalimat introgatif dengan inti kalimat berupa kata apakah. Jika dibaca secara keseluruhan, tampak bahwa kalimat tersebut tidak utuh sebab memiliki inti kata tanya apakah namun tidak memiliki intonasi final berupa tanda tanya (?). Di samping itu, kalimat tersebut juga terasa janggal jika dibaca keseluruhan. Dengan demikian, dapat disimpulkan bahwa kata amati merupakan inti kalimat tersebut sebab akan terjadi perubahan makna bila unsur tersebut dihilangkan.

Selanjutnya, pelesapan dilakukan dengan menghilangkan dua kata pada kalimat awal. Kata yang dilesapkan adalah amati dan apakah sehingga tampak seperti kalimat berikut.

(04b) Sambil kalian membaca teks, teks ini tergolong ke dalam laporan yang ideal.

Pelesapan kata-kata amati apakah telah merubah makna dan bentuk kalimat. Kalimat awal merupakan kalimat imperatif yang berfungsi untuk menyuruh $\mathrm{t}$ mengamati teks laporan sedangkan kalimat (04b) merupakan kalimat deklaratif yang berfungsi untuk menyatakan adanya teks yang tergolong dalam laporan yang ideal. Meski demikian, jika kalimat (04a) dibaca secara keseluruhan, kalimat tersebut tampak ganjal serta tidak utuh. Berdasarkan hal tersebut, dapat disimpulkan bahwa inti kalimat tersebut adalah kata amati.

Kalimat inperatif (04) secara tidak langsung memberi tugas pada t, $\mathrm{n}$ hanya megajak $\mathrm{t}$ untuk menganalisis dan memperkaya tugas yang telah diberikan sebelumnya. Selanjutnya terdapat kalimat imperatif yang secara langsung memerintahkan t untuk melakukan suatu tindakan yang tertulis secara langsung dalam kalimat, perhatikan data berikut.

(05) Bacalah teks laporan tentang harimau berikut ini. (Pr.De.1/17) 
Kalimat tersebut merupakan kalimat imperatif yang bertujuan untuk menyuruh $\mathrm{n}$ sebagai siswa membaca teks laporan tentang harimau yang disediakkan di dalam buku teks. Kata bacalah dalam data mengindikasikan $\mathrm{n}$ sebagai penulis menyuruh t sebagai siswa untuk melakukan kegiatan membaca. Penggunaan kata bacalah tersebut memberikan kesan tegas sebab dinyatakan secara langsung. Hal ini mengakibatkan tidak adanya pilihan kegiatan bagi siswa selain melakukan kegiatan membaca. Untuk mengetahui inti kalimat pada data (05), perhatikan kalimat berikut.

(05a) teks laporan tentang harimau berikut ini.

Kalimat di atas mengalami pelesapan dengan menghilangkan kata bacalah. Pelesapan tersebut mengakibatkan perubahan makna yang terkandung di dalamnya. Setelah mengalami pelesapan, kalimat tersebut tidak lagi berfungsi sebagai kalimat imperatif yang memiliki makna memerintah melainkan berfungsi sebagai kalimat deklaratif yang memiliki makna memberikan pernyataan. Kalimat (05a) memiliki makna tentang adanya sebuah teks laporan yang memiliki isi tentang harimau dalam buku teks. Dengan demikian, dapat disimpulkan bahwa kata "bacalah" merupakan inti kalimat sebab terjadi perubahan makna jika kata tersebut dilesapkan.

Selanjutnya, dilakukan pelesapan dua kata seperti yang tampak pada kalimat berikut.

(05b) Teks laporan tentang harimau berikut ini.

Makna yang ditimbulkan setelah dilakukan pelesapan dua kata sama halnya dengan makna yang ditimpulkan setelah dilakukan pelesapan satu kata. Kedua kalimat tersebut bermakna memberi tahukan $\mathrm{t}$ sebagai siswa atau pembaca tentang keberadaan laporan tentang harimau. Kesamaan makna antara kalimat pada pelesapan satu kata dan dua kata tersebut menandakan bahwa inti kalimat pada data (05) adalah kata bacalah. 
Dalam petunjuk perlatihan buku teks, sebagian besar data berupa kalimat imperatif yang memerintahkan t untuk melakukan suatu kegiatan baik berupa pengamatan ataupun berupa pengerjaan produk. Selanjutnya, data berikut ini merupakan kalimat imperatif dengan jenisnya untuk melakukan suatu kegiatan dan menghasilkan produk. perhatikan data berikut.

\section{Proses Dekategorisasi}

Dekategorisasi merupakan perubahan kalimat yang disebabkan karena hilangnya morfosintaksis dari kategori leksikal, sehingga dalam kalimat mengalami pengurangan-pengurangan morfosintaksisnya sehingga membentuk struktur baru. Dalam petunjuk pelatihan buku teks Bahasa Indonesia terdapat beberapa kalimat yang mengalami proses gramatikalisasi, diantaranya adalah teks sebagai berikut,

(6) Setelah kalian memahami struktur teks prosedur kompleks, sekarang coba perhatikan ciri kebahasaan yang digunakan pada teks "Apa yang Harus Anda Lakukan jika Ditilang?" (Pr/Dek/II/41)

Kalimat tersebut merupakan petunjuk lanjutan dari kegiatan yang telahh dilakukan sebelumnya. $\mathrm{N}$ tetap konsisten menggunakan kalimat direktif dalam penulisan petunjuknya dengan memberikan kata perhatikan. $\mathrm{N}$ ingin $\mathrm{t}$ untuk memperhatikan lebih seksama bacaan teks prosedur kompleks yang berjudul Apa yang Harus Anda Lakukan jika Ditilang?. Dalam petunjuk tersebut t dituntut untuk menganalisis cirri kebahasaan yang ada dalam teks. Cirri tersebut adalah pertisipan manusia, verba material, verba tingkah laku, dan konjungsi temporal. Untuk mengetahui keintian kata dalam kalimat tersebut maka dilakukan berbagai perubahan bentuk kalimat dengan mengurangi struktur morfologinya. Makna akan berbeda jika kalimat tersebut berubah menjadi sebagai berikut.

(6a) Sekarang coba perhatikan ciri kebahasaan yang digunakan pada teks" Apa yang Harus Anda Lakukan jika Ditilang?" 
(6b) Setelah kalian memahami struktur teks prosedur kompleks, perhatikan teks "Apa yang Harus Anda Lakukan jika Ditilang?"

Pengurangan struktur morfologi dalam kaliat (6a) menghilangkan jabatan keterangan dalam kalimat tersebut sehingga penulis secara langsung menjelaskan maksudnya untuk memperhatikan ciri kebahasaan dalam teks yang disediakan. Fungsi keterangan tersebut memberikan penjelasan urutan kegiatan siswa memperhatikan ciri kebahasaan harus dilakukan setelah menganalisis struktur teks. Namun dalam pengurangan tersebut tidak terdapat perubahan makna dalam petunjuk. $\mathrm{t}$ tetap memahami maksud dari $\mathrm{n}$ dalam memperhatikan cirri kebahasaan yang digunakan dalam teks. Dapat disimpulkan bahwa jabatan keterangan dalam kalimat tersebut bukanlah unsure inti karena pelesapannya tidak mengubah makna dalamkalimat.

Berbeda dengan kalimat (6a), kalimat (6b) mengaami pengurangan pada jabatan objek. Sehingga ciri kebahasaan yang digunakan merupkan petunjuk yang menjadi fokus dalam pengerjaan perlatihan. $\mathrm{N}$ memerintahkan agar $\mathrm{t}$ menganalisis berdasarkan ciri-ciri kebahasaan yang digunakan dalam teks yang akan dianalisis. Setelah unsur tersebut dilesapkan makan terjadi keambiguan dalam kalimat tersebut sehingga mengalami perubahan makna dan $t$ sulit dalam menyimpulkan makna yang terkandung dalam kalimat. Makna yang muncul akan berubah menjadi $\mathrm{n}$ menginginkan $\mathrm{t}$ untuk membaca dan memperhatikan teks yang berjudul "Apa yang Harus Anda Lakukan jika Ditilang?" tanpa memperhatikan unsur kebahasaannya. Dapat disimpulkan bahwa unsur objek dalam kalimat tersebut adalah unsur inti dalam kalimat yang tidak dapat dilesapkan. Jika dilesapkan makan makna akan berubah sehingga t mengalami keseulitan dalam memahami makna.

Berdasarkan data sebelumnya yang berbentuk direktif, data berikut ini merupakan data berbentuk deklaratif petunjuk dengan tidak menggunakan kata perintah secara langsung. 
7) Kalian diminta untuk menata kalimat tersebut dengan memberikan nomor urut pada setiap kalimat sehingga membentuk teks prosedur kompleks yang baik. (Pr/Dek/II/56)

Kalimat tersebut berbentuk deklaratif yang memberi pengarahan bagi siswa supaya memberikan nomor urut bagi setiap kalimat yang telah disediakan oleh penulis agar membentuk paragraf yang padu. Penggunaan kata kalian diminta mengindikasikan kalimat tersebut berbentu deklaratif. Namun makna yang muncul secara eksplisit adalah kalimat perinta bagi t. model direktif kalimat tersebut berbentuk pasif dengan menggunakan preposisi di- dalam kata diminta sehingga $\mathrm{n}$ tidak secara langsung member perintah pada t. untuk mengetahui kadar keintian kalimat dalam petunjuk tersebut, makan dilakukan berbagai perubahan dengan pengurangan beberapa unsur kalimat sebagai berikut.

(7a) Menata kalimat tersebut dengan memberikan nomor urut pada setiap kalimat sehingga membentuk teks prosedur kompleks yang baik.

(7b) Kalian diminta untuk menata kalimat tersebut sehingga membentuk teks prosedur kompleks yang baik.

Pada kalimat (7a) mengalami pelesapan pada bagian objek sehingga kalimat tersebut secara langsung memerintahkan siswa untuk menata susunan kalimat dalam buku teks supaya menjadi paragraph yang baik. Dari segi maknanya, kalimat tersebut tidak mengalami perubahan karena keinginan $\mathrm{n}$ sebagai penulis yang ingin siswa memberikan nomor pada tiap kata masih Nampak. Sedangkan dalam kalimat (7b) pelesapan bagian kalimat dilakukan pada predikat yaitu memberikan nomor urut pada setiap bagian sehingga kalimat tersebut bermakna $\mathrm{n}$ memeritahkan $\mathrm{t}$ untuk menata kalimat sehingga membentuk suatu wacana yang baik. Namun petunjuk tersebut berbeda dengan maksud utama $\mathrm{n}$ yang menginginkan siswa sebagai t menggunakan nomor urut untuk menyusun kalimat satu dengan kalimat yang lain. Berdasarkan data tersebut maka dapat dikatakan unsur predikat merupakan unsur inti, karena pelesapannya mengakibatkan berubahnya makna petunjuk buku teks. 


\section{Makna yang Muncul Akibat Proses Gramatikalisasi}

Dalam proses gramatikalisasi, akan ada perubahan makna akibat perubahan dan susunan gramatikal dalam perubahan bentuk dan struktur kalimat. Makna tersebut dapat berupa makna baru atau masih mempertahankan makna lama yang masih bertahan. Makna baru muncul apabila dalam kalimat tersebut dilesapkan atau ditambah unsur intinya. Akibat dari perubhan unsur kalimat inti maka pola pikir pembaca mengalami perubahan dalam memprediksikan maksud utaman dalam memberi petunjuk perlatihan pada $t$. Makna yang tidak mengalami perubahan merupakan kalimat yang unsur intinya tetap bertahan meskipun telah mengalami proses gramatikalisasi, sehingga maksud yang disampaikan $\mathrm{n}$ kepada t tetap sama dan tidak mengalami perubahan.

Berikut adalah beberapa hasil proses gramatikalisasi dari petunjuk perlatihan buku teks Bahasa Indonesia yang telah mengalami berbagai perubahan struktur kalimat. Dalam hasil penelitian, terdapat beberapa makna yang muncul diantaranya adalah makna konseptual, konotatif, stilistik, afektif, reflektif, kolokatif, dan tematik.

\section{Desemantisasi Afektif menjadi Tematik}

Makna afektif merupakan makna berdasarkan suassana hati dari penutur terhadap petutur yang menyebabkan perbedaan makna. Perbedaan kontek dan emosi menyebabkan perbedaan makna meskipun dengan kata yang sama. Makna afektif terlihat dalam kalimat petunjuk perlatihan buku teks dengan data (1) marilah kita uraikan teks berjudul makhluk di bumi ini (Mak/Des/ATem/01)

Kalimat tersebut bermakna afektif karena bernilai rasa terhadap suasana hati pengarang yang lebih sopan dengan menggunakan bahasa yang lebih halus dengan kata marilah. Bentuk persuasif dirasakan bernilai makna lebih lembut 
dibandingkan dengan direktif yang menggunakan kalimat perintah secara langsung.

Karenakan mengalami pengurangan unsur, makna kalimat berubah menjadi makna tematik yang memaknai kalimat berdasarkan cara $\mathrm{n}$ menyajikan kalimatnya berdasarkan urutan untuk menentukan fokus dan penekanan maksud n. penghilangan unsur marilah kita mengakibatkan kalimat memiliki makna tematik. Hal itu Nampak dikarenakan n terkesan menekankan maksudnya secara langsung dengan mengucapkan kata uraikan secara langsung di awal kalimat. Dalam kajian tematik, kata awal sebuah kalimat merupakan hal yang ditekankan atau yang diutamakan dalam kalimat. Sehingga $n$ menginginkan $t$ untuk menguraikan teks disampaikan secara langsung tanpa menggunakan gaya bahasa persuasif.

\section{Desemantisasi Tematik menjadi Konseptual}

Penekanan dan penegasan merupakan makna yang diutamakan pada tematik, pada data yang ditemukan di buku teks terdapat beberapa petunjuk perlatihan yang menggunakan makna tematik untuk menyusun terbentuknya wahana makna membantu t dalam memahami bacaan. Berikut adalah makna tematik dalam buku teks

(02) Bacalah teks pendek yang berjudul "Sistem Peredaran Darah Manusia" berikut ini (Mak/Des/TKon/02)

Data yang diperoleh di atas merupakan kalimat perintah yang secara tematik memerintahkan $\mathrm{t}$ untuk membaca sebuah teks pendek. Dikatakan tematik karena member penekanan pada kata bacalah yang merupakan kalimat perintah inti yang digunakan oleh $\mathrm{n}$. oleh karena itu, $\mathrm{n}$ memberikan fokus utama pada kata bacalah dengan cara meletakan kata perintah tersebut di awal kalimat. Jadi, dapat dikatakan bahwa kalimat tersebut bermakna tematik dengan menekankan membaca pada teks pendek yang berjudul Sistem Peredaran Darah Manusia yang telah disediakan oleh $\mathrm{n}$. 
Hindra Kurniawam, Gramatikalisasi dalam Petunjuk...(hal. 160 - 188)

Proses gramatikalisasi yang melesapkan beberapa bagian kalimat menyebabkan makna kalimat dapat berubah menjadi berbeda dengan awal. Pelesapan pada bagian bacalah sebagai unsur utama tematik meyebabkan kalimat tersebut berubah menjadi makna konseptual yang menjelaskan sebuah teks pendek yang berjudul sistem peredaran darah manusia dengan makna asli dan tidak menggunakan gaya bahasa ataupun nilai rasa yang terkandung dalam kalimat. Makna konseptual yang dapat diambil adalah $\mathrm{n}$ menunjuk sebuah teks pendek yang jumlah katanya tidak lebih dari lima ratus. Ukuran tersebut sudah menjadi patokan bahwa teks tersebut masuk dalam kategori pendek. Sebuah cerita pendek berjudul sistem peredaran darah manusia menjadi objek utama dalam kalimat dan merupakan makna leksikal

Data berikutnya merupakan data yang mengalami perubahan yang sama yaitu desemantisasi perubahan tematik menjadi konseptual. Perubahan tersebut terjadi karena gaya bahasa awal sebelum mengalami desemnatsasi berwujud tematik. Kalimat tersebut disebut tematik dikarenakan penekanan yang dilakukan oleh $\mathrm{n}$ tertuju pada satu maksud yang diutamakan. Berikut adalah data yang mengalami perubahan makna

(3) Bacalah teks laporan tentang harimau berikut ini. (Mak/Des/TKon/03)

Kalimat tersebut bermakna tematik disebabkan oleh penulis yakni $n$ menekankan suatu hal untuk disampaikan pada t dan memfokuskn pada satu makna. $\mathrm{N}$ memfokuskan pada kata bacalah sebagai fokus utama dalam kalimat perintah tersebut sehingga kesan memerintah lebih terasa karena kata perintah diletakkan pada awal kalimat. Berbeda jika frasa teks laporan tentang harimau diletakan di awal kalimat makan fokus utama kalimat merupakan untuk memperhatikan teks laporan tentang harimau yang ada dalam buku dan kata bacalah sebagai keterangan tambahan saja.

Setelah mengalami desemantisasi makan struktur kalimat akan berubah, begitu juga dengan maknannya. Pelesapan bacalah mengakibatkan kalimat 
tersebut bukan lagi sebuah kalimat direktif melainkan kalimat informatif. Makna yang muncul dari kalimat informatif adalah makna konseptual. Makna konseptual merupakan makna dari kalimat yang menerangkan makna denotative menerangkan makna asli dari kalimat. Konseptual muncul karena kalimat petunjuk menjadi teks laporan tentang harimau berikut ini. Kalimat tersebut mengungkapkan sebuah makna yang sebenarnya yaitu sebuah bacaan dalam bentuk teks laporan terperinci memuat informasi tentang harimau. Kalimat tersebut dikatakan kalimat asli karena tidak menggunakan gaya bahasa yang khas dan mengacu pada makna kata yang sebenarnya.

\section{Desemantisasi Tematik menjadi Kolokatif}

Makna tematik juga muncul dalam kalimat direktif berikut ini. Dengan menggunakan kata perintah pada awal kalimat yang menjadi fokus utama dalam pemaknaan kalimat. Perhatikan data berrkut ini

(04) perhatikan beberapa contoh pembentukan kata dari kata dasar menjadi kata bentukan yang lain berikut ini (Mak/Des/TKol/04)

Penekanan ide tau fokus utama kalimat tersebut ada dalam bentuk kata perintah perhatikan. $\mathrm{N}$ menekankan maksud secara langsung dengan memberikan kata perintah pada t. Dengan meletakkan kata perhatikan pada awal kalimat mengindikasikan jika n memusatkan perhatian pada bentuk kalimat perintah. Makna kalimat tersebut untuk memperhatikan beberapa contoh pembentukan kata yang berasal dari kata dasar menjadi kata lain karena mengalami penambahan unsur kata seperti imbuhan.

Setelah mengalami gramatikalisasi dengan teknik desemantisasi, makna kalimat petunjuk tersebut mengalami perubahan menjadi makna kolokatif. Makna kolokatif merupaka makna yang muncul sebagai akibat dari munculnya kata lain yang sejenis sehingga muncul kesatuan makna yang gramatikal. Makna kolokatif muncu karena kalimat menggunakan menggunakan kata yang sama dan sejenis untuk menjelaskan maksud yang dituju. Dalam petunjuk tersebut $n$ 
Hindra Kurniawam, Gramatikalisasi dalam Petunjuk...(hal. 160 - 188)

menulis mengunakan kata yang diulang-ulang namun dalam konteks yang berbeda. Pengulangan tersebut ada pada kata, ada berbagaimacam bentuk kata yang dibahas dalam kalimat ini untuk memperjelas bentuk kata yang akan dianalisis. T diberi tugas untuk menganalisis kata dasar menjadi kata bentukan dengan menganalisis perubahan bentuk yang dialami oleh tiap kata.

\section{Desemantisasi Tematik menjadi Reflektif}

Berikut adalah makna tematik dalam petunjuk pelatihan buku teks yang mengalami perubahan makna menjadi reflektif. Tematik adalah makna kalimat yang ditentukan berdasarkan fokus dan penekanan makna kalimat. Sedangkan reflektif merupakan makna yang berasal dari konsepsial ganda yang menimbulkan makna lain akibat dari proses gramatikalisasi. Berikut adalah data yang mengalami perubahan makna dari tematik menjdi reflektif

(05) Sambil kalian membaca teks, amati apakah teks ini tergolong ke dalam laporan yang ideal. (Mak/Des/TRef.1/05)

Kalimat tersebut mengandung makna tematik karena menyangkut cara $n$ menitik beratkan inti pokok kalimat. Dengan menempatkan inti pokok yang tepat maka akan diketahui penekanan mana maksud yang ingin disampaikan. Dengan kalimat tersebut $\mathrm{n}$ ingin menekankan kata perintah dengan cara tidak langsug. $\mathrm{N}$ mengesampingkan kata perintah dan mengutamakan kegiatan lain yang dilakukan. Jadi t akan melakukan dua kegiatan secara bersamaan, dengan cara $\mathrm{n}$ memerintahkan $\mathrm{t}$ untuk mengamati kualitas teks yang dibaca apakah termasuk idela atau tidak.

Hasil perubahan kalimat (05) mengalami perubahan makna menjadi reflektif. Makna reflektif merupakan bentuk baru dari petunjuk perlatihan (05) dikarenakan memiliki dua makna dalam satu kalimat. Dua makna tersebyt pertama adalah perintah untuk membaca taks bacaan dan makna kedua adalah mengamati teks yang dibaca apakah sudah masuk dalam criteria teks yang ideal. 
Karena memiliki dua makna menjadi satu maka kalimat tersebut memiliki makna reflektif sebagai gabungan dari kedua makna tersebut yang muncul makna baru. Makna yang muncu tidakjauh berbeda dengan makna asli, namun merupakan hasil peleburan dua makna menjadi satu. T dapat mengambil kesimpulan bahwa maksud $\mathrm{n}$ adalah untuk mengidentifikasi keidealan teks dengan membacanya.

Berikut adalah bentuk data lain yang mengalami perubahan yang sama dari bentuk tematik menjadi berbentuk reflektif.

(06) Buatlah kalimat yang di dalamnya terdapat kelompok nomina dengan penjenis dan kelompok nomina dengan pendeskripsi. (Mak/Des/TRef.1/06)

Kalimat tersebut memerintahkan $\mathrm{t}$ untuk membuat kalimat dengan kata yang sudah ditentukan oleh $n$, kata tersebut adalah jenis nomina penjenis dan nomina pendeskripsi. Nomina penjenis merupakan bentuk kata yang berfungsi utuk menentukan jenis apa benda tersebut, sebagai contoh burung berjenis merpati, berjenis kutilang, dan berjenis perkutut. Sedangkan nomina pendeskripsi merupakan gambaran dari objek yang diamati contohnya adalah burung kurus, harimau gemuk, jati meranggas, dll. Kalimat (06) berjenis tematik dikarenakan menggunakan kata imperatif diletakkan di awal kalimat sehingga $n$ menekankan kamsud utama untuk memerintah $\mathrm{n}$ melakukan sesuatu yang dijabarkan setelahnya.

Proses desemantisasi yang dialami oleh kalimat (06) mengakibatkan ia mengalami perubahan makna dan struktur kalimat, sehingga makna yang dapat muncul adalah makna reflektif. Makna reflektif muncul karena terdapat dua maksud yang dapat diambil. Maksud pertama adalah $\mathrm{n}$ memerintahkan $\mathrm{t}$ untuk membuat kalimat yang di dalamnya terdapat nomina penjenis. Sedangkan makna kedua hamper sama namun $\mathrm{n}$ memerintahkan membuat kalimat dengan nomina pendeskripsi di dalamnya. Dapat diambil kesimpulan bahwa makna reflektif dari kalimat (06) setelah mengalami desemantisasi adalah $t$ diperintahkan membuat dua jenis kalimat yang diantaranya adalah dengan 
nomina penjenis dan nomina pendeskripsi yang telah disediakan oleh $\mathrm{n}$ di dalam tabel dalam buku teks.

Berikut adalah bentuk data lain yang mengalami proses desemantisasi dengan berubahan makna dari tematik menjadi reflektif. Perubahan dari bentuk penekanan maksud kalimat dengan menempatkan maksud utama di awal kalimat berubah menjadi reflektif dengan pola konseptual ganda sehingga membentuk makna lain yang lebih kompleks. Perhatikan data berikut ini

(07) Lakukan observasi terhadap sesuatu yang telah kalian kenali di lingkungan alam sekitar. (Mak/Des/TRef.1/07)

Kalimat (07) merupakan kalimat petunjuk dalam buku teks dalam memberi pengarahan pada t untuk melakukan kegiatan yang dideskripsikan oleh $\mathrm{n}$. dalam penyusunan kalimat tersbut $\mathrm{n}$ menggunakan bentuk tematik. Bentuk tematik sering digunakan oleh $\mathrm{n}$ karena langsung terfokus pada makna yang dituju, tanpa berbelit-belit dan mudah dipahami oleh t. Petunjuk dengan makna tematik menempatkan kata perintah sebagai fokus utama dalam kalimat sehingga $n$ dengan secara langsung memerintahkan $t$ untuk melakukan sesuatu. Pada kalimat (07), n memerintah t untuk melakukan observasi terhadap sesuatu yang ada di alam sekitar yang telah familiar dengan $t$ sehingga lebih mudah untuk melakukan observasi. Jadi fokus utama tematik dalam kalimat tersebut adalah untuk melakukan observasi pada suatu hal, kata perintah untuk melakukan observasi diletakan pada awal kalimat supaya penekanan perintah lebih terasa.

Setelah mengalami perubahan desenatisasi, makna kalimat mengalami perubahan makna menjadi reflektif. Makna reflektif muncul ketika kata perintah dalam petunjuk perlatihan mengalami pelesapan sehingga kalimat yang tersisa menjadi reflektif. Dikatakan reflektif karena kalimat memiliki dua konseptual yang masing-masing membawa maknanya masing-masing sehingga bisa direfleksikan dalam bentuk baru. Konseptual pertama adalah melakukan 
obeservasi sebagai bentuk perintah utama, konseptual kedua adalah melakukan pengamatan pada lingkungan sekitar yang telah diketahui dan lebih familiar. Sehingga dapat ditarik kesipulan hasil reflekasi yaitu $\mathrm{t}$ diperintahkan untuk melakukan observassi pada sesuatu yang telah dikenal di lingkungan sekitar.

\section{SIMPULAN}

Gramatikalisasi merupakan fenomena yang terjadi berdasarkan penggunaan (usage-based phenomenon). Dengan kata lain, dalam gramatikalisasi, kejadian penggunaan (usage events) dapat menyebabkan terjadinya perubahan yang melibatkan arti-bentuk linguistik tertentu. Oleh karena itu, ciri utama gramatikalisasi adalah perubahan makna atau fungsi yang diasosiasikan dengan bentuk linguistik.

Pada awalnya, morfem leksikal memiliki banyak makna dan makna spesifik yang memiliki konteks penggunaan yang terbatas. Kemudian, morfem leksikal tersebut berubah menjadi morfem gramatikal yang memiliki tiga ciri-ciri berikut ini: 1) Morfem gramatikal kehilangan makna tertentu yang asalnya dimiliki oleh morfem leksikal sebelumnya, 2) Morfem gramatikal memiliki makna yang sangat luas dan bersifat abstrak atau relasional, dan 3. Morfem gramatikal dapat digunakan dalam konteks yang lebih luas dibandingkan sebelumnya, yaitu subjek menjadi lebih umum dan jenis verba yang menyertai morfem tersebut lebih beragam daripada sebelumnya.

Makna bahasa merupakan aspek terjadinya komunikasi di antara para penutur bahasa. Seperti dijelaskan pada pengertian ketiga, makna merupakan penghubung antara bahasa dengan alam di luar bahasa, atau antara ujaran dengan semua hal yang ditunjuknya, sesuai dengan kesepakatan para pemakai bahasa sehingga dapat saling mengerti dan terjadi komunikasi.

Sesuai dengan fokus dan tujuan penelitian yang disampaikan pada bab sebelumnya, serta setelah melewati tahap pengambilan data, dapat ditarik 
simpulan berkenaan denga gramatikalisai dalam petunjuk perlatihan buku teks kelas X Bahasa Indonesia sebagai berikut

Pertama ditemukannya proses desemantisasi yang dialami oleh petunjuk perlatihan dikarenakan oleh hilangnya unsur semantik dalam kata sehingga mengalami makna yang semakin sempit dan terfokus pada satu maksud tuturan. Dalam analisi desemantisasi ditemukan perubahan maksud kalimat sebagai hasil analisis sebagian berbeda dan ada yang sebagian mengalami kerancuan. Karena kerancuan tersebut dapat menyebabkan $t$ mengalami disorientasi tentang apa yang harus dilakukan terhadap tugas yang telah diberikan oleh $\mathrm{n}$.

Perubahan makna dalam desemantisasi yaitu makna afektif menjadi temati, makna tematik menjadikonseptual, makna tematik menjadi kolokatif, dan makna afektif menjadi konotatif. Perubahan makna tersebut tidak lepas dari proses desemantisasi namun makna tersebut memiliki nilai rasa yang berbeda di setiap jenisnya.

\section{DAFTAR RUJUKAN}

Aitchison, Jean. 2004. Linguistics: Teach Yourself. McGraw-Hill Companies: USA Clark, H.E. and Clark, E.V. 1977. Psychology and Language: An Introduction to Psycholinguistics. New York: Harcourth Brace Jovanovich Inc.

Halliday, MAK. 2004. An Introduction to Function Gramar. London: Oxford University Press Inc.

Keraf, Gorys. 1997. Tata Bahasa Indonesia. Ende: Nusa Indah

Kridalaksana, Harimurti. 1994. Kelas Kata dalam Bahasa Indonesia. Gramedia Pustaka Utama: Jakarta.

Maleong, lexy j. 2002. Metodologi Penelitian Kualitatif. Bandung : Remaja Rosda Karya

Muslich, Masnur. 2010. Teks Books Writing: Dasar Pemahaman, Penulisan, dan Pemakaian Buku Teks. Yogyakarta: Ar-ruzz Media. 
Rahardi. 2004. Media Pembelajaran. Jakarta: Direktorat Tenaga Pendidikan , Departemen, Pendidikan Nasional.

Santoso, Anang. 2008. Jejak Halliday Dalam Linguistik Kritis dan Analisis Wacana Kritis. Jurnal Bahasa dan Seni Tahun 36 No 1. Fakutas Sastra: Universitas Negeri Malang

Sudaryanto. 1993. Metode dan Aneka Teknik Analisis Bahasa: Pengantar Penelitian Wahana Kebudayaan Secara Linguistis. Yogyakarta: Duta Wacana University Press.

Kridalaksana, Hari Murti. 1984. Keutuhan Wacana dalam Majalah Pengajaran Bahasa dan Sastra tahun IV No 1. Jakarta: Pusat Pembinaan dan Pengembangan Bahasa. Depdikbud. 